\title{
Isoflavone Aglycone Content and the Thermal, Functional, and Structural Properties of Soy Protein Isolates Prepared from Hydrothermally Treated Soybeans
}

\author{
Ana Paula Wally-Vallim, Nathan Levien Vanier, Elessandra da Rosa Zavareze, Rui Carlos Zambiazi, Luis Antônio Suita de \\ Castro, Manoel Artigas Schirmer, and Moacir Cardoso Elias
}

\begin{abstract}
Soybeans were hydrothermally treated at 2 different temperatures $\left(40{ }^{\circ} \mathrm{C}\right.$ and $\left.60{ }^{\circ} \mathrm{C}\right)$ and for 4 different hydration times $(4,8,12$, and $16 \mathrm{~h})$ to (i) increase the isoflavone aglycone content in a soy protein isolate and (ii) evaluate the changes in thermal, functional, and structural properties of a soy protein isolate as a function of hydrothermal treatment conditions. Our study is the first to evaluate aglycone content, extraction yield, $\beta$-glucosidase activity, differential scanning calorimetry, protein digestibility, scanning electron microscopy, water absorption capacity (WAC), foaming capacity (FC), and foaming stability of soy protein isolates prepared from hydrothermally treated soybeans. For aglycone enhancement and the extraction yield maintenance of soy protein isolates, the condition of $40{ }^{\circ} \mathrm{C}$ for $12 \mathrm{~h}$ was the best soybean hydrothermal treatment. The structural rearrangement of proteins that occurred with the hydrothermal treatment most likely promoted the capacity of proteins to bind to aglycone. Moreover, the structure shape and size of soy protein isolates verified by scanning electron microscopy appears to be related to the formation of hydrophobic surfaces and hydrophobic zones at $40{ }^{\circ} \mathrm{C}$ and $60{ }^{\circ} \mathrm{C}$, respectively, affecting the protein digestibility, WAC, and FC of soy protein isolates.
\end{abstract}

Keywords: aglycone, functional properties, isoflavone, soy protein

Practical Application: The aglycone content in the soy protein isolate can be improved with the hydrothermal treatment of soybeans. The temperature and time used for hydrothermal treatment must be selected in order to achieve a soy protein isolate with high aglycone content, extraction yield, and functionality. This technology is suitable for providing healthier soy protein isolates for food industry with improved functional and structural properties.

\section{Introduction}

Traditionally known as a good source of protein and lipids, soybeans have been widely used in Asian countries as the raw material for several soy-based foods, such as tofu, tempeh, and soymilk. Recently, the knowledge of health benefits promoted by soybean proteins and phytochemicals has increased interest in soy-based foods by Western populations. Many nutritional health benefits of soybean consumption have been attributed to isoflavones, mainly related to women's health. These health benefits include protection against uterine carcinoma (Eason and others 2005) and the relief of menopausal symptoms (Nahas and others 2007). Isoflavones are also used to treat airway inflammatory disease (Bao and others 2011), and their antioxidant activities can prevent oxidative damage (Dixit and others 2012).

Isoflavones can occur in the form of aglycones (daidzein, genistein, and glycitein) and $\beta$-glucoside conjugates, which include

MS 20131697 Submitted 11/17/2013, Accepted 4/27/2014. Authors WallyVallim, Vanier, Zavareze, Zambiazi, Schirmer, and Elias are with Depto. de Ciência e Tecnologia Agroindustrial, Univ. Federal de Pelotas, 96010-900, Capão do Leão, Brazil. Author Wally-Vallim is with Inst. Federal Sul-Riograndense, Campus Pelotas - Visconde da Graça, 96060-290, Pelotas, Brazil. Author Castro is with Embrapa Clima Temperado, Rodovia BR 392, km 78, Caixa Postal 403, 96010-971, Pelotas, Brazil. Direct inquiries to authorVanier(E-mail:nathanvanier@hotmail.com). glucosides, malonylglucosides, and acetylglucosides (Tipkanon and others 2010). According to Izumi and others (2000), the $\beta$ glucosidase produced in the gastrointestinal tract hydrolyzes glucosides to aglycones, which are absorbed more rapidly and in higher amounts than their glucosides by humans due to the lower hydrophilicity of aglycones and their lower molecular weights.

Among the soy products used for human consumption, soy protein isolate is widely used in the food industry because of its functional properties. Wang and Murphy (1996) studied the mass balance of isoflavones during soybean processing and verified that only $39.9 \%$ of the isoflavones in soy protein isolate are aglycones. Similarly, Shao and others (2009) studied the isoflavone profile of soy protein isolates prepared from low-, medium-, and highisoflavone content soybeans and reported that aglycones comprise $46.7 \%, 47.7 \%$, and $38.5 \%$ of the total isoflavones, respectively. Thus, alternative processing technologies must be developed to improve isoflavone aglycones in soy protein isolates as a method for providing healthier food products to the world's population. Some of this processing includes soaking, fermentation, coagulation, and protein precipitation.

When soybeans are soaked in water, the endogenous $\beta$ glucosidase present in the grain is activated, hydrolyzing the isoflavone glucoside forms to their aglycone forms ( $\mathrm{Ha}$ and others 1992). The $\beta$-glucosidase activity varies as a function of hydration time and temperature (Tipkanon and others 2010). The 
hydrothermal treatment of soybeans has been used to improve the aglycone levels in soybean grains (Carrão-Panizzi and others 2004; Góes-Favoni and others 2010) and in soy germ flour (Tipkanon and others 2010); however, the effects of time and temperature used during soybean hydrothermal treatment with a focus on the soy protein isolate have not been studied.

The objective of this study was to evaluate the aglycone content and the thermal, functional, and structural properties of soy protein isolates prepared from hydrothermally treated soybeans at 2 different temperatures $\left(40^{\circ} \mathrm{C}\right.$ and $\left.60^{\circ} \mathrm{C}\right)$ and 4 different hydration times $(4,8,12$, and $16 \mathrm{~h})$.

\section{Materials and Methods}

\section{Material}

Soybeans (Glycine max L. Merril) were cultivated on a farm at Capão do Leão in the State of Rio Grande do Sul, Brazil, and were harvested when the moisture content was approximately $13 \%$. The grains were subsequently submitted to a cleaning process. Subsequently, the grains were treated hydrothermally. All the chemicals used in this study were of analytical grade or better.

\section{Hydrothermal treatment}

The soybeans $(100 \mathrm{~g})$ were distributed in perforated bags within a beaker, covered with distilled water 1:5 (w/v), and submitted to 2 different temperatures $\left(40^{\circ} \mathrm{C}\right.$ and $\left.60^{\circ} \mathrm{C}\right)$ and 4 different hydration times $(4,8,12$, and $16 \mathrm{~h})$, in triplicate. The beakers containing the samples were distributed in a water bath (Bubnoff, Quimis, Diadema, Brazil) under a controlled temperature of $40^{\circ} \mathrm{C}$ or $60^{\circ} \mathrm{C}$. The grains were dried in an oven (at the end of each hydration time) at $40{ }^{\circ} \mathrm{C}$ under forced air flow until the moisture content reached $13 \%$. Next, the grains were ground in a laboratory mill (Perten 3100, Perten Instruments, Sweden). Nonhydrothermally treated soybeans were used as the control treatment.

The temperatures used in this study were intended to cover a temperature range above and below the critical temperature of soybean protein denaturation to detect a possible change in aglycone formation and functional properties of the proteins as a function of protein interaction with isoflavones.

\section{Protein isolates preparation and extraction yield}

The soybean flour was de-fatted using petroleum ether (LabSynth, Brazil). The soybean protein isolates were prepared ac-

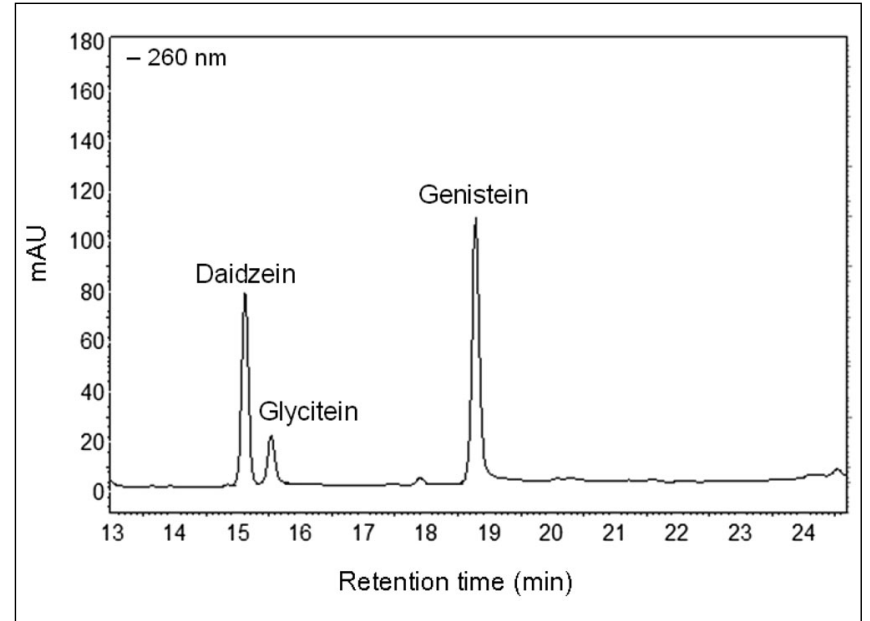

Figure 1-Mixture of isoflavones standard analyzed by high pressure liquid chromatography (HPLC). cording to the method described by Lui and others (2003). The de-fatted flour $(50 \mathrm{~g})$ was suspended in $1 \mathrm{~L}$ of distilled water and the $\mathrm{pH}$ was adjusted to 9.0 using $\mathrm{NaOH}(4 \mathrm{~N})$. The slurry was heated for $45 \mathrm{~min}$ at $55^{\circ} \mathrm{C}$ under continuous stirring. The slurry was then centrifuged (Excelsa ${ }^{\mathrm{TM}}$ II, Mod. 206 BL, Fanem, São Paulo, Brazil) at $13000 \times g$ for $20 \mathrm{~min}$ at $25^{\circ} \mathrm{C}$. The residue was collected and lyophilized (Micromodulyo E2 M2, Edwards). This fraction was referred to as the insoluble residue. The supernatant was also collected and its $\mathrm{pH}$ adjusted to 4.1 with $\mathrm{HCl}(6 \mathrm{~N})$. It was mixed for $1 \mathrm{~h}$ for protein precipitation according to its isoelectric point. After acid precipitation, the slurry was centrifuged (Excelsa II) at $13000 \times g$ for $20 \mathrm{~min}$ at $5{ }^{\circ} \mathrm{C}$, and the precipitated material (soybean protein isolate) and the supernatant were collected and lyophilized.

The extraction yield of soy protein isolates was measured according to the formula: Extraction yield $(\%)=\{[$ amount of soy protein isolate $(\mathrm{g}) /$ amount of de-fatted flour $(\mathrm{g})] \times 100\}$.

\section{Isoflavone extraction}

The isoflavone extraction was performed according to the method described by Fukutake and others (1996), with modifications. Each sample (1 g) was transferred to a volumetric flask $(10 \mathrm{~mL})$. Methanol (80\%) (LabSynth) was added to the flask, and the extraction proceeded for $2 \mathrm{~h}$. Next, the slurry was centrifuged (Microcentrífuga - NT800, Nova Técnica, São Paulo, Brazil) at $9000 \mathrm{rpm}$ for $6 \mathrm{~min}$. The supernatant was transferred to a $1.5 \mathrm{~mL}$ vial and used for aglycone quantification.

\section{Isoflavone quantification using high-performance liquid chromatography (HPLC)}

The quantification of the aglycones was performed by HPLC according to the method described by Carrão-Panizzi and others (2004).

The extract was purified prior to the HPLC analysis; the first step utilized common filter paper, and the 2nd step was accomplished with a $0.45-\mu \mathrm{m}$ syringe filter (FHLP 1300 PVDF, Millipore, Billerica, Mass., U.S.A.). Next, $10 \mu \mathrm{L}$ of extract was injected in the HPLC system equipped with a single pump (model LC-10ATVP, Shimadzu, Japan), a solvent delivery module (FCV10ALVP, Shimadzu, Japan), a degassing pump (DGU-14A, Shimadzu, Japan), a system controller (SCL-10ATVP, Shimadzu, Japan), a block heater oven (CTO-10ASVP, Shimadzu, Japan), and an auto sampler (SIL-10AF, Shimadzu, Japan). The HPLC separation of all of the compounds was performed using a chromatographic octadecyl reverse-phase Supelcosil ${ }^{\mathrm{TM}}$ LC-18 column $(25 \mathrm{~cm} \times 4.6 \mathrm{~mm} \times 5 \mu \mathrm{m})$. A UV/VIS detector was used for detection at $260 \mathrm{~nm}$ (UV/VIS SPD-10AVVP, Shimadzu, Japan).

A gradient elution was performed at a flow rate of $0.9 \mathrm{~mL} / \mathrm{min}$, initially using an $80 \%$ aqueous mobile phase $(0.1 \%$ acetic acid in Milli-Q water) and a $20 \%$ organic mobile phase (consisting of $0.1 \%$ acetic acid in acetonitrile). The mobile phase proportion was changed over $15 \mathrm{~min}$ until a ratio of $50 \%$ aqueous mobile phase to $50 \%$ organic mobile phase was achieved. After $25 \mathrm{~min}$, the mobile phase proportion was changed to $100 \%$ organic mobile phase $(0.1 \%$ acetic acid in acetonitrile), which was maintained until the 35 min mark. Next, the mobile phase linearly returned to the initial condition, totaling $40 \mathrm{~min}$ of analysis. The column temperature ranged from $25^{\circ} \mathrm{C}$ to $35^{\circ} \mathrm{C}$. The data were analyzed using Class-VP software.

The aglycone quantification was based on an external standard using an analytical calibration curve constructed with standards solutions of daidzein (98\% purity, Sigma-Aldrich, St. Louis, 
Table 1-Aglycone content ( $\mu$ g aglycone/g dry weight) of soy protein isolates prepared with hydrothermally treated soybeans at different time and temperature conditions.

\begin{tabular}{|c|c|c|c|c|c|c|}
\hline \multirow[b]{2}{*}{ Aglycones } & \multirow[b]{2}{*}{ Temperature $\left({ }^{\circ} \mathrm{C}\right)$} & \multirow[b]{2}{*}{ Control } & \multicolumn{4}{|c|}{ Time (h) } \\
\hline & & & 4 & 8 & 12 & 16 \\
\hline \multirow[t]{2}{*}{ Daidzein } & 40 & $93.03 \mathrm{aD}^{\mathrm{a}}$ & $99.74 \mathrm{bD}$ & $161.84 \mathrm{bC}$ & $223.93 \mathrm{bA}$ & $207.82 \mathrm{bB}$ \\
\hline & 60 & $93.03 \mathrm{aE}$ & $112.95 \mathrm{aD}$ & $170.77 \mathrm{aC}$ & $243.09 \mathrm{aA}$ & $219.72 \mathrm{aB}$ \\
\hline \multirow[t]{2}{*}{ Glycitein } & 40 & $29.40 \mathrm{aD}$ & $33.90 \mathrm{aD}$ & $66.40 \mathrm{bC}$ & $98.00 \mathrm{bB}$ & $117.60 \mathrm{aA}$ \\
\hline & 60 & $29.40 \mathrm{aE}$ & $48.30 \mathrm{bD}$ & $82.70 \mathrm{aC}$ & $114.10 \mathrm{aB}$ & $122.80 \mathrm{aA}$ \\
\hline \multirow[t]{2}{*}{ Genistein } & 40 & $97.84 \mathrm{aE}$ & $144.80 \mathrm{bD}$ & $220.00 \mathrm{bC}$ & $295.10 \mathrm{bA}$ & $230.90 \mathrm{bB}$ \\
\hline & 60 & $97.84 \mathrm{aE}$ & $153.40 \mathrm{aD}$ & $235.43 \mathrm{aB}$ & $312.40 \mathrm{aA}$ & $242.90 \mathrm{aC}$ \\
\hline \multirow[t]{2}{*}{ Total } & 40 & $220.27 \mathrm{aE}$ & $278.52 \mathrm{bD}$ & $447.40 \mathrm{bC}$ & $626.98 \mathrm{bA}$ & $556.27 \mathrm{aB}$ \\
\hline & 60 & $220.27 \mathrm{aE}$ & $314.69 \mathrm{aD}$ & $488.87 \mathrm{aC}$ & $669.55 \mathrm{aA}$ & $585.38 \mathrm{aB}$ \\
\hline
\end{tabular}

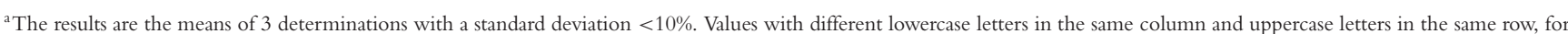
each aglycone compound, are significantly different $(P<0.05)$.

Mo., U.S.A.), glycitein (98\% purity, Sigma-Aldrich), and genistein (98\% purity, Sigma-Aldrich). The retention times for daidzein, glycitein, and genistein were 15.3, 15.6, and $18.9 \mathrm{~min}$, respectively (Figure 1).

\section{Protein content}

The nitrogen content was determined using the AACC method 46-13 (AACC 1995), and the protein content was obtained using a conversion factor of nitrogen to protein of 6.25.

\section{$\beta$-glucosidase activity}

The $\beta$-glucosidase activity in soybeans after hydrothermal treatment was determined according to the method described by Góes-Favoni and others (2010). One hundred milligrams sample of soy flour, and $1.5 \mathrm{~mL}$ of $0.05 \mathrm{M}$ citrate buffer ( $\mathrm{pH} 4.5$ ) containing $0.1 \mathrm{M} \mathrm{NaCl}$ was maintained for $1 \mathrm{~h}$ at room temperature. The samples were centrifuged and the supernatant was kept for enzyme activity analysis. Two milliliters of the substrate $1 \mathrm{mM}$ $p$-nitrophenyl- $\beta$-D-glucopyranoside ( $p$-NPG) (Sigma Chemical Co., St. Louis, EUA) in phosphate-citrate buffer (0.1 M pH 5.0) were transferred to a test tube and kept in a water bath at $30{ }^{\circ} \mathrm{C}$ for $10 \mathrm{~min}$; then $0.5 \mathrm{~mL}$ of the supernatant was added and the tube left in the water bath at $30{ }^{\circ} \mathrm{C}$ for $30 \mathrm{~min}$. The reaction was stopped with $2.5 \mathrm{~mL}$ of $0.05 \mathrm{M}$ sodium carbonate and the contents were immediately measured in a spectrophotometer at $420 \mathrm{~nm}$. The blank solution was composed of $2.5 \mathrm{~mL}$ of $0.05 \mathrm{M}$

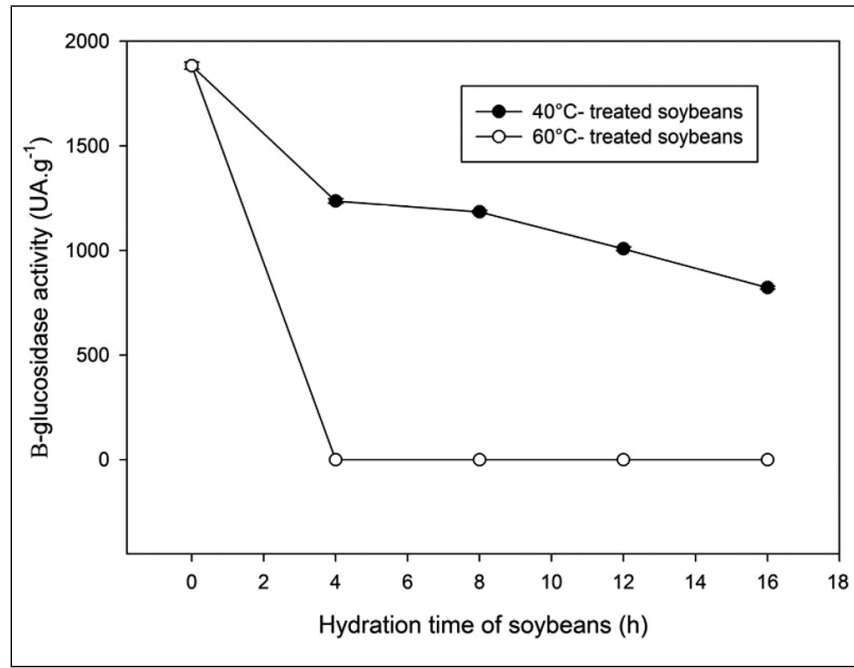

Figure 2-Residual $\beta$-glucosidase activity of soybeans after the hydrothermal treatment at $40^{\circ} \mathrm{C}$ and $60^{\circ} \mathrm{C}$ for $4,8,12$, and $16 \mathrm{~h}$. sodium carbonate solution, $2.0 \mathrm{~mL}$ of substrate solution, and 0.5 $\mathrm{mL}$ of $0.05 \mathrm{M}$ citrate buffer ( $\mathrm{pH} 4.5$ ) containing $0.1 \mathrm{M} \mathrm{NaCl}$. The para-nitrophenol ( $p-\mathrm{NP})$ released by the action of the enzyme was determined by referring to a calibration curve prepared from the $p$-NP (Sigma-Aldrich Co., St. Louis, Miss., U.S.A.) in concentrations that varied from 5 to $300 \mu \mathrm{M}$, according to Matsuura and Obata (1993). One activity unit (UA) was defined as the quantity of enzyme necessary to release $1 \mu \mathrm{mol}$ of $p$-NP per minute under the experimental conditions. Results were expressed as $\beta$-glucosidase activity level (UA/g of sample on dry weight).

\section{Differential scanning calorimetry (DSC)}

Thermal characteristics of the soybean protein isolates were determined using DSC (TA-60 WS, Shimadzu, Kyoto, Japan). Protein isolate samples (approximately $2.5 \mathrm{mg}$ on a dry basis) were weighed directly in an aluminum pan (Mettler, ME-27331), and distilled water was added to obtain an aqueous suspension containing $75 \%$ water. The pan was hermetically sealed and allowed to equilibrate for $1 \mathrm{~h}$ before analysis. An empty pan was used as a reference. The sample pans were then heated from $20^{\circ} \mathrm{C}$ to $110^{\circ} \mathrm{C}$ at a rate of $10^{\circ} \mathrm{C} / \mathrm{min}$. The onset temperature of denaturation $\left(T_{\mathrm{o}}\right)$, the peak temperature of denaturation $\left(T_{\mathrm{p}}\right)$, and the denaturation enthalpy $(\Delta H)$ were determined.

\section{In vitro protein digestibility}

The in vitro protein digestibility was determined in accordance with the method described by Pinto and others (2005). Aqueous protein solutions in $0.1 \mathrm{~N} \mathrm{HCl}(10 \mathrm{mg} / \mathrm{mL})$ were hydrolyzed with pepsin for $3 \mathrm{~h}$ at $37{ }^{\circ} \mathrm{C}$ under mild agitation, with a ratio of enzyme to substrate of 1:25. The hydrolysis was interrupted by adding trichloroacetic acid to a final concentration of $5 \%$. After centrifugation $(10000 \times g$ for $20 \mathrm{~min})$, the supernatant aliquots were used for nitrogen determination according to the Kjeldahl method (AACC 1995). Two blanks were prepared, a sample blank containing the protein sample under study and an enzyme blank, containing only the protease used. Casein was used as a control in each determination. The correlation between total nitrogen and nitrogen of the hydrolysate (supernatant) allows for the estimation of protein digestibility via the following formula: Protein digestibility $(\%)=[(N$ digested $\times 100) / N$ total $]$.

\section{Scanning electron microscopy}

The structure of the lyophilized soy protein isolates was examined using a scanning electron microscope (Shimadzu, SSX-550, Japan). The material was initially suspended in acetone to obtain a $1 \%(\mathrm{w} / \mathrm{v})$ suspension, and the samples were maintained in an ultrasound for $15 \mathrm{~min}$. A small quantity of each sample was spread 
Table 2-Aglycone and protein retention in soy protein isolate, insoluble residue and supernatant, and extraction yield $(\%$ of the initial de-fatted flour) of soy protein isolates as affected by time and temperature of soybean hydrothermal treatment.

\begin{tabular}{|c|c|c|c|c|c|c|c|c|}
\hline \multirow[b]{2}{*}{$\begin{array}{l}\text { Temperature } \\
\left({ }^{\circ} \mathrm{C}\right)\end{array}$} & \multirow[b]{2}{*}{$\begin{array}{l}\text { Time } \\
\text { (h) }\end{array}$} & \multicolumn{2}{|c|}{ Soy protein isolate } & \multicolumn{2}{|c|}{ Insoluble residue } & \multicolumn{2}{|c|}{ Supernatant } & \multirow[b]{2}{*}{$\begin{array}{c}\text { Extraction yield } \\
(\%)\end{array}$} \\
\hline & & $\begin{array}{c}\text { Protein } \\
\text { retention }(\%)\end{array}$ & $\begin{array}{c}\text { Aglycones } \\
\text { retention (\%) }\end{array}$ & $\begin{array}{c}\text { Protein } \\
\text { retention }(\%)\end{array}$ & $\begin{array}{c}\text { Aglycones } \\
\text { retention (\%) }\end{array}$ & $\begin{array}{c}\text { Protein } \\
\text { retention }(\%)\end{array}$ & $\begin{array}{c}\text { Aglycones } \\
\text { retention (\%) }\end{array}$ & \\
\hline Control & & $82.7 \pm 2.7 \mathrm{a}^{\mathrm{a}}$ & $28.8 \pm 0.9 \mathrm{e}^{\mathrm{a}}$ & $13.2 \pm 0.4 \mathrm{e}$ & $7.1 \pm 0.5 \mathrm{~g}$ & $4.1 \pm 0.1 \mathrm{c}$ & $64.1 \pm 0.5 \mathrm{a}$ & $40.01 \pm 1.26 \mathrm{a}^{\mathrm{a}}$ \\
\hline \multirow[t]{4}{*}{40} & 4 & $83.9 \pm 3.1 \mathrm{a}$ & $32.1 \pm 1.8 \mathrm{~d}$ & $13.4 \pm 0.9 \mathrm{e}$ & $4.4 \pm 0.3 \mathrm{~h}$ & $2.7 \pm 0.2 \mathrm{e}$ & $63.5 \pm 1.0 \mathrm{a}$ & $41.46 \pm 1.90 \mathrm{a}$ \\
\hline & 8 & $82.8 \pm 3,5 \mathrm{a}$ & $45.2 \pm 1.6 \mathrm{~b}$ & $14.0 \pm 0.5 \mathrm{e}$ & $12.7 \pm 0.3 \mathrm{e}$ & $3.2 \pm 0.2 \mathrm{~d}$ & $42.0 \pm 0.4 \mathrm{~b}$ & $38.75 \pm 1.30 \mathrm{a}$ \\
\hline & 12 & $77.1 \pm 1.4 \mathrm{~b}$ & $52.5 \pm 1.4 \mathrm{a}$ & $19.0 \pm 1.7 \mathrm{~d}$ & $14.4 \pm 0.5 \mathrm{~d}$ & $3.9 \pm 0.2 c$ & $33.1 \pm 0.5 \mathrm{~d}$ & $36.02 \pm 1.05 \mathrm{~b}$ \\
\hline & 16 & $68.4 \pm 3.4 c$ & $46.2 \pm 2.3 \mathrm{~b}$ & $27.7 \pm 1.9 \mathrm{c}$ & $19.5 \pm 0.7 \mathrm{c}$ & $3.9 \pm 0.1 \mathrm{c}$ & $34.4 \pm 3.3 \mathrm{~d}$ & $32.05 \pm 1.79 \mathrm{c}$ \\
\hline \multirow[t]{4}{*}{60} & 4 & $53.4 \pm 1.2 \mathrm{~d}$ & $27.9 \pm 0.2 \mathrm{e}$ & $42.0 \pm 1.4 \mathrm{~b}$ & $8.9 \pm 0.7 \mathrm{f}$ & $4.6 \pm 0.1 \mathrm{a}$ & $63.1 \pm 0.3 \mathrm{a}$ & $28.27 \pm 0.72 \mathrm{de}$ \\
\hline & 8 & $44.5 \pm 2.4 \mathrm{e}$ & $36.6 \pm 1.7 \mathrm{c}$ & $50.7 \pm 2.2 \mathrm{a}$ & $26.1 \pm 0.8 \mathrm{a}$ & $4.8 \pm 0.1 \mathrm{a}$ & $37.2 \pm 0.2 \mathrm{c}$ & $22.44 \pm 1.23 \mathrm{f}$ \\
\hline & 12 & $54.2 \pm 2.2 \mathrm{~d}$ & $54.2 \pm 2.6 \mathrm{a}$ & $43.1 \pm 0.6 \mathrm{~b}$ & $21.4 \pm 0.4 \mathrm{~b}$ & $2.6 \pm 0.2 \mathrm{e}$ & $24.4 \pm 0.4 \mathrm{e}$ & $26.95 \pm 1.76 \mathrm{e}$ \\
\hline & 16 & $54.5 \pm 0.7 \mathrm{~d}$ & $54.7 \pm 1.1 \mathrm{a}$ & $42.2 \pm 0.2 \mathrm{~b}$ & $25.0 \pm 0.6 \mathrm{a}$ & $3.3 \pm 0.1 \mathrm{~d}$ & $20.3 \pm 0.2 \mathrm{f}$ & $29.29 \pm 0.34 \mathrm{~d}$ \\
\hline
\end{tabular}

${ }^{a}$ The values are the means of 3 determinations \pm standard deviation and represent the percentage of de-fatted flour proteins and aglycones in each fraction obtained during the soy protein isolation process. Values with different lowercase letters in the same column are significantly different $(P<0.05)$.

Table 3-Differential scanning calorimetry of soy protein isolates prepared with hydrothermally treated soybeans at different time and temperature conditions.

\begin{tabular}{|c|c|c|c|c|c|c|c|c|}
\hline \multirow[b]{2}{*}{ Temperature $\left({ }^{\circ} \mathrm{C}\right)$} & \multirow[b]{2}{*}{ Time (h) } & \multicolumn{3}{|c|}{$\beta$-Conglycinin (7S) } & \multicolumn{3}{|c|}{ Glycinin (11 S) } & \multirow{2}{*}{$\begin{array}{c}\text { Total enthalpy } \\
\Delta H(\mathrm{j} / \mathrm{g})\end{array}$} \\
\hline & & $T_{\mathrm{o}}\left({ }^{\circ} \mathrm{C}\right)$ & $T_{\mathrm{p}}\left({ }^{\circ} \mathrm{C}\right)$ & $\Delta H(\mathrm{~J} / \mathrm{g})$ & $T_{\mathrm{o}}\left({ }^{\circ} \mathrm{C}\right)$ & $T_{\mathrm{p}}\left({ }^{\circ} \mathrm{C}\right)$ & $\Delta H(\mathrm{j} / \mathrm{g})$ & \\
\hline Control & & $72.54^{\mathrm{a}}$ & 76.20 & 0.66 & 83.60 & 90.69 & 2.19 & 2.85 \\
\hline \multirow[t]{4}{*}{40} & 4 & 73.19 & 77.71 & 0.43 & 84.73 & 91.90 & 1.57 & 2.00 \\
\hline & 8 & 74.38 & 78.48 & 0.10 & 83.62 & 90.64 & 1.37 & 1.47 \\
\hline & 12 & 74.98 & 77.23 & 0.84 & 84.53 & 90.96 & 1.73 & 2.57 \\
\hline & 16 & 73.22 & 77.74 & 0.58 & 84.97 & 92.27 & 2.26 & 2.84 \\
\hline \multirow[t]{4}{*}{60} & 4 & 74.52 & 78.78 & 0.19 & 85.19 & 92.42 & 0.84 & 1.03 \\
\hline & 8 & 75.17 & 77.97 & 0.17 & 84.61 & 90.79 & 1.77 & 1.94 \\
\hline & 12 & 70.94 & 71.54 & 0.15 & 85.37 & 90.62 & 2.49 & 2.64 \\
\hline & 16 & nd & nd & nd & 84.54 & 91.34 & 1.66 & 1.66 \\
\hline
\end{tabular}

${ }^{\mathrm{a}}$ The results are the means of 2 determinations.

$T_{\mathrm{o}}$, onset temperature of denaturation; $T_{\mathrm{p}}$, peak temperature of denaturation; $\Delta H$, enthalpy of denaturation.

Table 4-In vitro protein digestibility (\%), water absorption capacity (g/g), foaming capacity (FC; \%), and foaming stability (FS; \%) of soy protein isolates prepared with hydrothermally treated soybeans at different time and temperature conditions.

\begin{tabular}{|c|c|c|c|c|c|c|}
\hline & \multirow{2}{*}{$\begin{array}{c}\text { Temperature } \\
\left({ }^{\circ} \mathrm{C}\right)\end{array}$} & \multirow[b]{2}{*}{ Control } & \multicolumn{4}{|c|}{ Time (h) } \\
\hline & & & 4 & 8 & 12 & 16 \\
\hline \multirow[t]{2}{*}{ In vitro protein digestibility (\%) } & 40 & $72.0 \pm 1.2 \mathrm{aC}^{\mathrm{d}}$ & $71.4 \pm 1.9 \mathrm{aC}$ & $85.5 \pm 1.5 \mathrm{aB}$ & $86.2 \pm 1.0 \mathrm{aB}$ & $88.7 \pm 1.3 \mathrm{aA}$ \\
\hline & 60 & $72.0 \pm 1.2 \mathrm{aB}$ & $66.5 \pm 1.5 \mathrm{bC}$ & $70.5 \pm 1.7 \mathrm{bB}$ & $72.7 \pm 1.2 \mathrm{bAB}$ & $74.6 \pm 2.0 \mathrm{bA}$ \\
\hline \multirow[t]{2}{*}{ WAC $(\mathrm{g} / \mathrm{g})^{\mathrm{a}}$} & 40 & $3.35 \pm 0.1 \mathrm{aA}^{\mathrm{d}}$ & $2.96 \pm 0.2 \mathrm{bB}$ & $3.09 \pm 0.1 \mathrm{bB}$ & $3.12 \pm 0.1 \mathrm{bB}$ & $2.97 \pm 0.2 \mathrm{bB}$ \\
\hline & 60 & $3.35 \pm 0.1 \mathrm{aB}$ & $3.07 \pm 0.2 \mathrm{aC}$ & $3.43 \pm 0.1 \mathrm{aB}$ & $4.09 \pm 0.2 \mathrm{aA}$ & $3.58 \pm 0.2 \mathrm{aB}$ \\
\hline \multirow[t]{2}{*}{$\mathrm{FC}(\%)^{\mathrm{b}}$} & 40 & $66.67 \pm 0.9 \mathrm{aE}^{\mathrm{d}}$ & $70.27 \pm 2.2 \mathrm{bD}$ & $80.24 \pm 1.9 \mathrm{bC}$ & $84.26 \pm 1.4 \mathrm{bB}$ & $106.33 \pm 2.5 \mathrm{aA}$ \\
\hline & 60 & $66.67 \pm 0.9 \mathrm{aB}$ & $90.33 \pm 1.4 \mathrm{aA}$ & $90.33 \pm 2.1 \mathrm{aA}$ & $92.27 \pm 1.5 \mathrm{aA}$ & $90.10 \pm 1.9 \mathrm{bA}$ \\
\hline \multirow[t]{2}{*}{ FS $(\%)^{c}$} & 40 & $76.16 \pm 0.2 \mathrm{aB}^{\mathrm{d}}$ & $76.42 \pm 0.3 \mathrm{bB}$ & $90.04 \pm 0.3 \mathrm{bA}$ & $89.29 \pm 1.1 \mathrm{bA}$ & $90.66 \pm 0.9 \mathrm{aA}$ \\
\hline & 60 & $76.16 \pm 0.2 \mathrm{aD}$ & $93.27 \pm 0.2 \mathrm{aA}$ & $93.27 \pm 0.5 \mathrm{aA}$ & $91.32 \pm 0.7 \mathrm{aB}$ & $83.60 \pm 0.2 \mathrm{bC}$ \\
\hline
\end{tabular}

${ }^{a}$ Water absorption capacity.

${ }^{\mathrm{b}}$ Foaming capacity.

${ }^{\mathrm{c}}$ Foaming stability.

${ }^{\mathrm{d}}$ The results are the means of 3 determinations \pm standard deviation. Values with different lowercase letters in the same column and uppercase letters in the same row, for each analysis, are significantly different $(P<0.05)$.

directly onto the surface of the stub and dried in an oven at $32{ }^{\circ} \mathrm{C}$ for $1 \mathrm{~h}$. Subsequently, all of the samples were coated with gold and examined in the scanning electron microscope under an acceleration voltage of $15 \mathrm{kV}$ and magnifications of $20 \times$ and $100 \times$.

\section{WAC, foaming capacity (FC), and foaming stability (FS)}

The WAC was determined according to the method described by Sosulski and others (1976). A $500 \mathrm{mg}$ sample was homogenized in $5 \mathrm{~mL}$ distilled water for $1 \mathrm{~min}$ and allowed to stand for 30 min at $25{ }^{\circ} \mathrm{C}$. Next, the material was centrifuged (Excelsa II) at $1200 \times g$ for $30 \mathrm{~min}$. The supernatant was then removed, and the precipitated material was weighed. The WAC was measured according to the following equation: WAC $(\mathrm{g} / \mathrm{g})=\{[$ weight of precipitate $(\mathrm{g}) /$ weight of initial sample $(\mathrm{g})] \times 100\}$.

The FC and FS were recorded according to the methods described by Phillips and others (1987) and Dipak and Kumar (1986), respectively. For each protein isolate, $3.0 \mathrm{~g}$ was suspended in 100 $\mathrm{mL}$ of distilled water. The slurry was allowed to stand for $10 \mathrm{~min}$ at $25^{\circ} \mathrm{C}$. Next, the slurry was vortexed for $1 \mathrm{~min}$ and transferred to a $250 \mathrm{~mL}$ beaker, where the volume was measured before and after the mixing of the slurry. The FC was calculated according to the following formula: FC $(\%)=\{[($ vol. after mixing - vol. before mixing) $/$ vol. before mixing] $\times 100\}$. The FS was analyzed by allowing the slurry to stand for $15 \mathrm{~min}$ after the mixing step. 


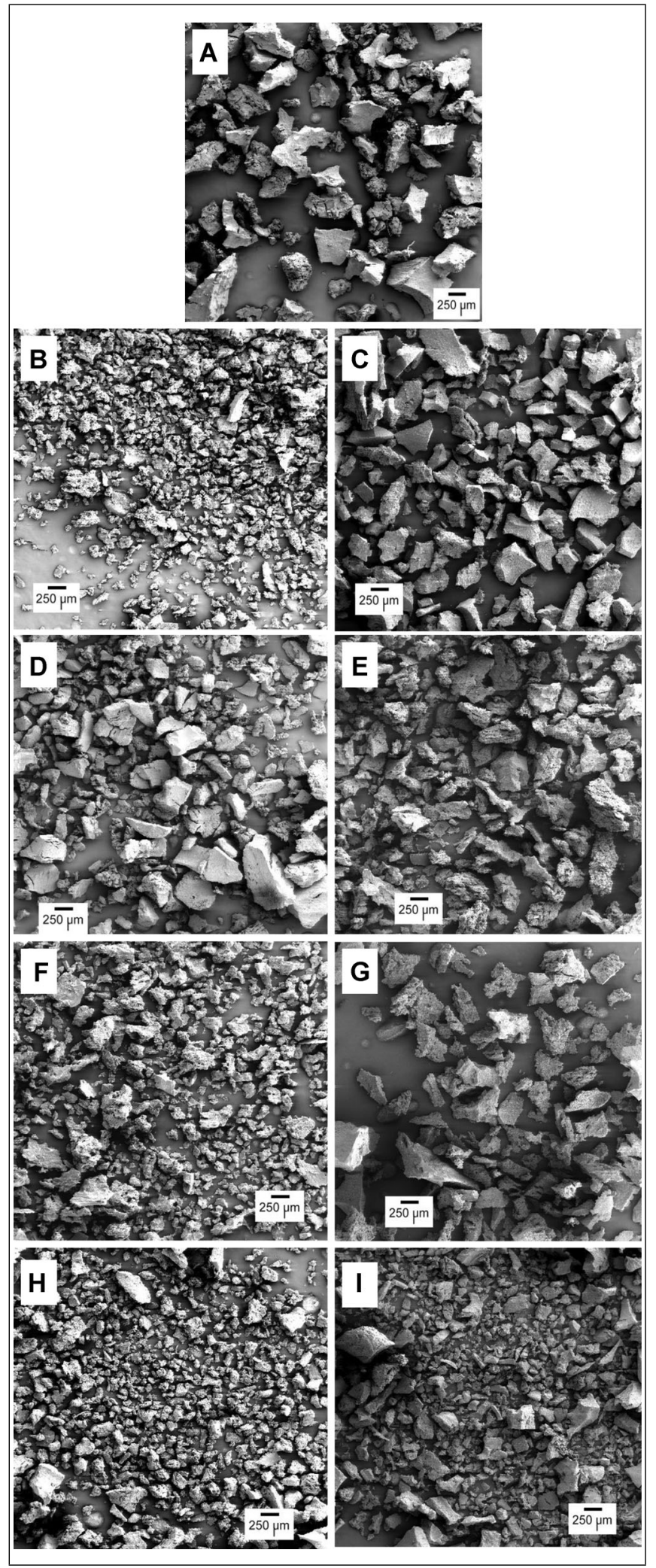

Figure 3-Scanning electron micrographs of soy protein isolates (SPI) prepared from hydrothermally treated soybeans at $20 x$ magnification: $(A)$ control treatment; (B) SPI from $40{ }^{\circ} \mathrm{C}, 4$ h-treated soybeans; (C) SPI from $60{ }^{\circ} \mathrm{C}$, 4 h-treated soybeans; (D) SPI from $40{ }^{\circ} \mathrm{C}, 8 \mathrm{~h}$-treated soybeans; (E) SPI from $60^{\circ} \mathrm{C}, 8 \mathrm{~h}$-treated soybeans; (F) SPI from $40^{\circ} \mathrm{C}, 12 \mathrm{~h}$-treated soybeans; (G) SPI from $60^{\circ} \mathrm{C}, 12 \mathrm{~h}$-treated soybeans; (H) SPI from $40^{\circ} \mathrm{C}$, $16 \mathrm{~h}$-treated soybeans; (I) SPI from $60^{\circ} \mathrm{C}, 16 \mathrm{~h}$-treated soybeans.
The FS was calculated according to the following formula: FS (\%) $=[$ (volume after $15 \mathrm{~min} /$ volume after mixing $) \times 100]$.

\section{Statistical analysis}

Analytical determinations for the samples were performed in triplicate, except for DSC, which was performed twice. A comparison of the means was ascertained by Tukey's test to a $5 \%$ level of significance using analysis of variance (ANOVA).

\section{Results and Discussion}

\section{Aglycone content of soy protein isolates as affected by hydrothermal treatment of soybeans}

The aglycone contents of the soy protein isolates are presented in Table 1. The hydrothermal treatment of soybeans increased the aglycone content in the protein isolates (Table 1). The aglycone distribution profile remained unchanged with the hydrothermal treatments, with genistein composing the majority of the aglycones, followed by daidzein and glycitein (Table 1). Daidzein and genistein increased with an increased time of hydration up to $12 \mathrm{~h}$ at both $40{ }^{\circ} \mathrm{C}$ and $60{ }^{\circ} \mathrm{C}$. There was a reduction in the total aglycones of the soy protein isolate in the samples treated for $16 \mathrm{~h}$ at both $40{ }^{\circ} \mathrm{C}$ and $60{ }^{\circ} \mathrm{C}$ compared to the soy protein isolate prepared from $12 \mathrm{~h}$ hydrothermally treated grains (Table 1$)$. According to Carrão-Panizzi and others (2004), the hydrothermal treatment of soybean promotes an increase in its $\beta$-glucosidase activity. We did not verify $\beta$-glucosidase activity in soybeans treated at $60{ }^{\circ} \mathrm{C}$; however, it was verified in soybeans treated at $40{ }^{\circ} \mathrm{C}$ (Figure 2). Similar results were verified by Lima and Ida (2014), who reported no enzyme activity of soybeans hydrated at temperatures around $60^{\circ} \mathrm{C}$. The authors explained that $\beta$-glucosidase losses stability after its peak activity (Lima and Ida 2014). This fact can justify the decrease in $\beta$-glucosidase activity of soybeans treated at $40{ }^{\circ} \mathrm{C}$ as a function of hydration time, as well as justify the absence of $\beta$-glucosidase activity in soybeans hydrated at $60^{\circ} \mathrm{C}$. The reduction in total aglycones when $16 \mathrm{~h}$ of hydrothermal treatment was used compared to $12 \mathrm{~h}$ most likely occurred as a function of the thermal instability of isoflavones and/or aglycone leaching to the soaking water. According to Malaypally and Ismail (2010), isoflavones become unstable when proteins are denatured given that proteins act to protect isoflavones.

\section{Protein and aglycone retention in soy protein isolates as affected by hydrothermal treatment of soybeans}

The protein and aglycone retention in the soy protein isolate, the insoluble residue, and the supernatant during the protein isolation process are presented in Table 2. Initially, the de-fatted soy flour was composed of $55.3 \%$ of crude protein and $321.98 \mu \mathrm{g} / \mathrm{g}$ of aglycones (data not shown). After the analysis of each fraction obtained during the protein isolation process, the soy protein isolate fraction with the highest retention of proteins was from de-fatted soybean flour $(82.7 \%)$, followed by the insoluble residue $(13.2 \%)$ and the supernatant $(4.1 \%)$. The hydrothermal treatment of soybeans before protein isolation changed the protein retention percentage in the 3 fractions (soy protein isolate, insoluble residue, and supernatant). The reduction and the increase in protein retention in the soy protein isolate and the insoluble residue, respectively, are related to the decrease in the extraction yield of the soy protein isolate (Table 2). This conclusion can be drawn given that the protein content of soy protein isolates was similar in the control and in the hydrothermally treated samples, varying 
between $92.6 \%$ and $96.4 \%$ (data not shown). There was an increase in protein retention in the insoluble residue (Table 2) and a consequent decrease in the extraction yield of soy protein isolate (Table 2) from soybeans treated for 12 and $16 \mathrm{~h}$ at $40{ }^{\circ} \mathrm{C}$ and for all the hydration times at $60{ }^{\circ} \mathrm{C}$ compared to the control (protein isolate from nonthermally treated soybeans). The protein isolates from soybeans treated at $60{ }^{\circ} \mathrm{C}$ showed a lower extraction yield than the protein isolates from soybeans treated at $40{ }^{\circ} \mathrm{C}$ (Table 2). The structural rearrangement of proteins and denaturation can insolubilise proteins, preventing their extraction during the protein isolation process and increasing their retention in the insoluble residue, as verified in Table 2 , where the insoluble residue from $60{ }^{\circ} \mathrm{C}$-treated soybeans showed a higher protein retention than the $40{ }^{\circ} \mathrm{C}$-treated soybeans.

The aglycones of the control treatment were distributed mainly in the supernatant, which retained $64.1 \%$ of the aglycones initially present in the de-fatted flour used for the protein isolation process (Table 2). A similar result was observed by Lui and others (2003), who reported an isoflavone retention of $52.0 \%$ in the supernatant. The hydrothermal treatment promotes an increase in aglycone retention in soy protein isolates, except for the $4 \mathrm{~h}$ and $60{ }^{\circ} \mathrm{C}$ treatment (Table 2). The highest aglycone retention percentage in a soy protein isolate was found when the soybeans were hydrothermally treated at $40{ }^{\circ} \mathrm{C}$ for $12 \mathrm{~h}(52.5 \%)$, at $60{ }^{\circ} \mathrm{C}$ for 12 $\mathrm{h}(54.2 \%)$, and at $60{ }^{\circ} \mathrm{C}$ for $16 \mathrm{~h}(54.7 \%$; Table 2$)$. The changes in the structural arrangement of proteins that occurs with hydrothermal treatment most likely promote the capacity of proteins to bind to aglycones. According to Wolf (1979), the thermal denaturation and dissociation of proteins promotes structural unfolding and the exposure of hydrophobic groups. These hydrophobic groups have affinity to phenolic compounds, such as aglycones (Naczk and others 2006). Accordingly, there was also an increase in aglycone retention in the insoluble residue fraction that contain fibers and proteins (data not shown), from $7.1 \%$ in the control treatment to $12.7 \%, 14.4 \%$, and $19.5 \%$ in the insoluble residue obtained from the 8,12 , and 16 h-treated soybeans at $40{ }^{\circ} \mathrm{C}$, respectively, and to $8.9 \%, 26.1 \%, 21.4 \%$, and $25.0 \%$ in the insoluble residue from the $4,8,12$, and 16 h-treated soybeans at $60^{\circ} \mathrm{C}$ (Table 2). This makes the insoluble residue more attractive to industrial applications.

\section{Differential scanning calorimetry}

The protein isolates were evaluated for thermally induced changes using DSC. The DSC thermograms of protein isolates showed 2 peaks. According to Liu and others (2008), the 1st peak represents the $7 \mathrm{~S}$ fraction ( $\beta$-Conglycinin), while the 2 nd one represents the $11 \mathrm{~S}$ fraction (Glycinin).
The onset temperature of denaturation $\left(T_{\mathrm{o}}\right)$, the peak temperature of denaturation $\left(T_{\mathrm{p}}\right)$, and the denaturation enthalpy $(\Delta H)$ from DSC analysis of the soy protein isolates are presented in Table 3. The $T_{\mathrm{o}}$ and $T_{\mathrm{p}}$ of the $\beta$-Conglycinin fraction varied from $70.94^{\circ} \mathrm{C}$ to $75.17^{\circ} \mathrm{C}$ and $71.54^{\circ} \mathrm{C}$ to $78.78{ }^{\circ} \mathrm{C}$, respectively. The $T_{\mathrm{o}}$ and $T_{\mathrm{p}}$ of the Glycinin fraction varied from $83.60^{\circ} \mathrm{C}$ to $85.37{ }^{\circ} \mathrm{C}$ and $90.62{ }^{\circ} \mathrm{C}$ to $92.42^{\circ} \mathrm{C}$, respectively. Similar results were verified by Sorgentini and others (1995), who reported $74{ }^{\circ} \mathrm{C}$ and $83{ }^{\circ} \mathrm{C}$ for the onset and peak temperatures of $\beta$-Conglycinin, respectively.

The $\Delta H$ represents the energy required to change the structure of the protein and/or to promote protein denaturation. When $\Delta H$ is reduced, it can be due to the structural rearrangement and/or partial denaturation of proteins. When $\Delta H$ disappears, it indicates that the denaturation was total. The soy protein isolate prepared from hydrothermally treated soybeans at $60^{\circ} \mathrm{C}$ and $16 \mathrm{~h}$ did not yield denaturation temperatures $\left(T_{\mathrm{o}}\right.$ and $\left.T_{\mathrm{p}}\right)$ and, consequently, did not present enthalpy $(\Delta H)$ of the $\beta$-Conglycinin protein fraction (Table 3). At $60^{\circ} \mathrm{C}$ and $16 \mathrm{~h}$ of hydrothermal treatment, only the Glycinin fraction showed $T_{\mathrm{o}}, T_{\mathrm{p}}$, and $\Delta H$. The higher thermal stability of Glycinin compared to $\beta$-Conglycinin is due to its 21 disulfide bonds, of which 15 are intrasubunit and 6 are intersubunit (Damodaran 1988). Given that $\beta$-Conglycinin does not contain disulfide bonds, it shows lower stability against thermal treatment and, thus, lower $T_{\mathrm{o}}$ and lower $\Delta H$ than Glycinin. In comparing hydrothermally treated and nontreated soy protein isolates, hydrothermal treatment did not induce major changes in the protein electrophoretic patterns (data not shown), suggesting that hydrothermal treatment at $40^{\circ} \mathrm{C}$ and $60{ }^{\circ} \mathrm{C}$ for as long as 16 $\mathrm{h}$ did not modify the protein profiles of soy protein isolate.

\section{In vitro protein digestibility}

The in vitro protein digestibility of soy protein isolates is presented in Table 4. The soy protein isolates prepared at $40{ }^{\circ} \mathrm{C}$ over 8,12 , and $16 \mathrm{~h}$ showed higher protein digestibility than the control treatment (Table 4). The increase in protein digestibility is most likely due to a structural rearrangement and/or a partial denaturation that occurred in the proteins, according to the decrease in the total $\Delta H$ from the DSC analysis (Table 4). Protein denaturation changes the protein conformation, maintaining its primary structure intact, implying a better protein digestibility by exposing new sites for enzymatic attack. When $60{ }^{\circ} \mathrm{C}$ was used for the hydrothermal treatment, there was an intense structural rearrangement, which was confirmed by the decrease in $\Delta H$ from DSC analysis. This rearrangement was particularly indicated by the absence of $T_{\mathrm{o}}, T_{\mathrm{p}}$, and $\Delta H$ of $\beta$-Conglycinin when the soybeans
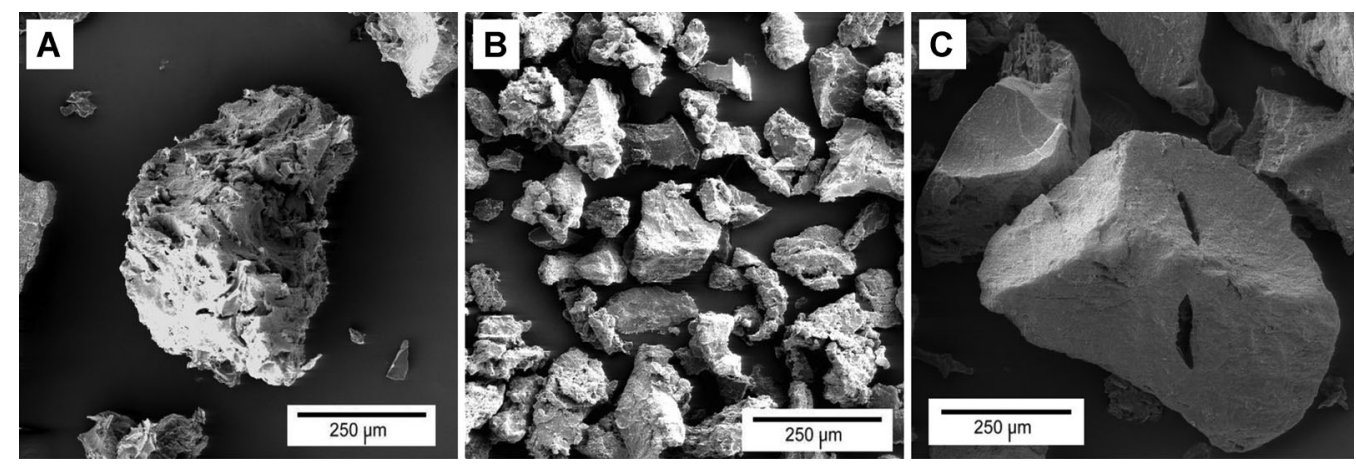

Figure 4-Scanning electron micrographs of soy protein isolates (SPI) prepared from hydrothermally treated soybeans at $100 \times$ magnification: (A) control treatment; (B) SPI from $40^{\circ} \mathrm{C}, 16 \mathrm{~h}$-treated soybeans; (C) SPI from $60^{\circ} \mathrm{C}, 16 \mathrm{~h}$-treated soybeans. 
were treated at $60^{\circ} \mathrm{C}$ over $16 \mathrm{~h}$, indicating total denaturation of the $7 \mathrm{~S}$ fraction (Table 3). Thus, enzyme attack becomes more difficult. These data are in agreement with Privalov (1979), who proposed a 2-step denaturation of globular proteins. The conversion of a native protein to a denatured state involves first the dissociation of the protein subunit followed by the disruption of hydrophobic interactions. However, at higher temperatures, denaturation occurs more intensively and is irreversible, characterized by reaggregation through the exposed hydrophobic regions and disulfide bonds. In addition, the increase in aglycone content most likely contributes to decrease the protein digestibility of the isolates from the $60^{\circ} \mathrm{C}$-treated soybeans. According to Stanley and Aguilera (1985), phenolics can form complexes with proteins, making proteins unavailable to enzymatic reactions.

\section{Scanning electron microscopy}

Scanning electron microscopy of the soy protein isolates at a magnification of $20 \times$ was performed to understand the effect of the temperature and time used in the hydrothermal treatment of soybeans on the particle size distribution of the protein isolates (Figure 3). The lyophilized soy protein isolates from $40{ }^{\circ} \mathrm{C}$-treated soybeans (clearly observed in Figure $3 \mathrm{~B}, 3 \mathrm{~F}$, and $3 \mathrm{H}$ ) in general had smaller and more heterogeneous structures than the control treatment (Figure 3A). Moreover, the soy protein isolate from $60{ }^{\circ} \mathrm{C}$-treated soybeans for $12 \mathrm{~h}$ of hydration time (Figure 3C, 3E, and $3 \mathrm{G}$ ) did not differ with respect to particle size compared to the control treatment (Figure 3A). In addition, the structures were more homogeneous and were larger than for the $40^{\circ} \mathrm{C}$-treated soybean.

Figure 4 compares the particle surface of soy protein isolates prepared from $40{ }^{\circ} \mathrm{C}$ for $16 \mathrm{~h}$-treated soybeans and $60{ }^{\circ} \mathrm{C}$ for 16 h-treated soybeans compared to control at a magnification of 100-fold. The soy protein isolate from the control treatment (nonhydrated soybeans before protein isolation) showed an irregular surface, as observed in Figure $4(\mathrm{~A})$. When $40{ }^{\circ} \mathrm{C}$ was used during hydrothermal treatment for the most severe hydration time of our study (Figure 4B), there was a reduction in the structure size, but the structure appears to continue with an irregular surface. However, when $60^{\circ} \mathrm{C}$ was used as the hydrothermal treatment for the same $16 \mathrm{~h}$ (Figure 4C), the structure size was similar to the control, but the surface was smoother. These results may be due to the changes in temperature leading to an unfolding of the soy protein molecules at $40{ }^{\circ} \mathrm{C}$, with an exposure of hydrophobic groups on the surface of the molecules. A similar phenomenon was reported by $\mathrm{Hu}$ and others (2013), who studied the effects of ultrasound treatment on the structural properties of soy protein isolate dispersions. The hydrothermal treatment of soybeans at $60{ }^{\circ} \mathrm{C}$ most likely promoted an interaction of the hydrophobic surfaces, allowing for the formation of larger aggregates during freeze-drying than those from $40^{\circ} \mathrm{C}$-treated soybeans.

\section{WAC, FC, and FS}

The WAC, the FC, and the FS of the protein isolates prepared with hydrothermally treated soybean grains are presented in Table 4.

There was a decrease in the WAC of the protein isolates from $40{ }^{\circ} \mathrm{C}$-treated soybeans and for the soy protein isolate prepared from $60{ }^{\circ} \mathrm{C}$ and $4 \mathrm{~h}$-treated soybeans. However, in soy protein isolates from $60^{\circ} \mathrm{C}$-treated soybeans for 8 and $16 \mathrm{~h}$, the WAC was in the same range as the control (Table 4). There was an increase in the WAC in the protein isolate prepared from the $60{ }^{\circ} \mathrm{C}$ and $12 \mathrm{~h}$-treated soybeans compared to the control. According to
Wagner and others (2000), protein denaturation increases its superficial hydrophobicity, promoting water repulsion. This explains the reduction in the WAC of isolates from $40^{\circ} \mathrm{C}$-treated soybeans. Takeiti and others (2004) reported that mild denaturation conditions cause the exposure of protein hydrophobic regions, reducing their WAC. When $60{ }^{\circ} \mathrm{C}$ was used for the hydrothermal treatment of soybeans, there was a partial denaturation of proteins (as verified in the DSC analysis) that possibly promoted the interaction of hydrophobic surfaces, allowing for the formation of new hydrophobic zones. The formation of hydrophobic zones promotes the reduction in water repulsion of the soy protein isolates, explaining why the soy protein isolates from the $60{ }^{\circ} \mathrm{C}$-treated soybeans reacquired the WAC to the same level or higher than the control treatment.

The FC increased in the protein isolates prepared from hydrothermally treated soybeans compared to control (Table 4). There was a continuous increase in the $\mathrm{FC}$ of the protein isolates prepared from $40{ }^{\circ} \mathrm{C}$-treated soybeans as a function of hydration time $(4,8,12$, and $16 \mathrm{~h})$. However, the FC of the protein isolates prepared from $60{ }^{\circ} \mathrm{C}$-treated soybeans increased when $4 \mathrm{~h}$ of hydration was used and remained unchanged for as long as 16 $\mathrm{h}$ of hydration at $60^{\circ} \mathrm{C}$ (Table 4). The FS increased in protein isolates prepared from $40{ }^{\circ} \mathrm{C}$-treated soybeans during 8,12 , and $16 \mathrm{~h}$ of hydration and increased in protein isolates prepared from $60{ }^{\circ} \mathrm{C}$-treated soybeans for $4,8,12$, and 16 h of hydration compared to control (Table 4). The highest FS was verified in isolates prepared from $60^{\circ} \mathrm{C}$-treated soybeans when 4,8 , and $12 \mathrm{~h}$ of hydration were used. However, when $16 \mathrm{~h}$ of hydration was used, the lowest temperature $\left(40{ }^{\circ} \mathrm{C}\right)$ promoted a higher FS than the $60{ }^{\circ} \mathrm{C}$ treatment (Table 4$)$.

In addition to the WAC, the protein unfolding that occurred in soybeans treated at $40{ }^{\circ} \mathrm{C}$ most likely exposed the hydrophobic surfaces of the proteins, allowing for an increase in the FC with an increase in hydration time. The highest extent of hydrophobic surfaces in soy protein isolates provides a great ability for the material to form bubbles by air occlusion in the nonpolar spaces from molecules. When soybeans were submitted to $60{ }^{\circ} \mathrm{C}$ during hydrothermal treatment, there was a strong structural rearrangement and/or denaturation of proteins (as reported in sections "Differential scanning calorimetry" and "Scanning electron microscopy") that increased the FC to a maximum degree during the first 4 $\mathrm{h}$, remaining unchanged until $16 \mathrm{~h}$ of hydrothermal treatment at $60^{\circ} \mathrm{C}$ (Table 4).

\section{Conclusion}

Our study focused on aglycone content and thermal, functional, and structural properties of soy protein isolate, being the 1 st one to evaluate soy protein isolates prepared from hydrothermally treated soybeans under different time and temperature conditions. It was possible to increase the aglycone content of soy protein isolates by hydrothermal treatment of soybeans. Considering the observed aglycone enhancement and the extraction yield maintenance of soy protein isolates, we conclude that $40{ }^{\circ} \mathrm{C}$ for $12 \mathrm{~h}$ is the best soybean hydrothermal treatment used, providing a $184.6 \%$ increase in aglycone content with only a $10.0 \%$ decrease in extraction yield. The changes in structural arrangement of proteins that occurred with the hydrothermal treatment most likely promoted the capacity of the proteins to bind to aglycones.

The structural and functional characteristics of soy protein isolates were also affected by the hydrothermal treatment of soybeans. The soy protein isolates from soybeans that were treated at $60{ }^{\circ} \mathrm{C}$ for as long as $12 \mathrm{~h}$ showed a smooth surface, while those isolates 
from $40{ }^{\circ} \mathrm{C}$-treated soybeans showed an irregular surface and smaller structures than the control treatment. This structure shape and size appears to be related to the formation of hydrophobic surfaces and hydrophobic zones at $40^{\circ} \mathrm{C}$ and $60{ }^{\circ} \mathrm{C}$, respectively, affecting the protein digestibility, WAC, and $\mathrm{FC}$ of soy protein isolates.

\section{Acknowledgments}

We would like to thank CAPES (Coordenação de Aperfeiçoamento de Pessoal de Nível Superior), CNPq (Conselho Nacional de Desenvolvimento Científico e Tecnológico), FAPERGS (Fundação de Amparo à Pesquisa do Estado do Rio Grande do Sul), SCT-RS (Secretaria da Ciência e Tecnologia do Estado do Rio Grande do Sul), and Polo de Inovação Tecnológica em Alimentos da Região Sul.

\section{References}

American Association of Cereal Chemists - AACC. 1995. Approved methods. 10 ed. Saint Paul, Minn.: AACC.

Bao ZS, Hong L, Guan Y, Dong XW, Zheng HS., Tan GL, Xie QM. 2011. Inhibition of airway inflammation, hyperresponsiveness and remodeling by soy isoflavone in a murine model of allergic asthma. Intl Immunopharmacol 11(8):899-906.

Carrão-Panizzi MC, Góes-Favoni SP, Kikuchi A. 2004. Hydrotermal treatments in the development of isoflavone aglycone in soybean (Glycine Max (L.) Merril) grains. Brazilian Arch Biol Technol 47(2):225-32

Damodaran S. 1988. Refolding of thermally unfolded soy proteins during the cooling regime of the gelation process: effect on gelation. J Agric Food Chem 36(2):2629.

Dipak K, Kumar KD. 1986. Functional properties of rapeseed protein products with varying phytic acid contents. J Agric Food Chem 34:775-77.

Dixit AM, Bhatnagar D, Kumar V, Chawla D, Fakhruddin K, Bhatnagar D. 2012. Antioxidant potential and radioprotective effect of soy isoflavone against gamma irradiation induced oxidative stress. J Funct Foods 4:197-206.

Eason RR, Till SR, Velarde MC, Geng Y, Chatman Jr. L, Gu L, Badger TM, Simmen FA, Simmen RC. 2005. Uterine phenotype of young adult rats exposed to dietary soy or genistein during development. J Nutr Biochem 16:625-32.

Fukutake M, Takahashi M, Ishida K, Kawamura H, Sugimura T, Wakabayashi K. 1996. Quantification of genistein and genistin in soybeans and soybeans products. Food Chem Toxicol 34(5):457-61.

Góes-Favoni SP, Carrão-Panizzi MC, Beleia A. 2010. Changes of isoflavone in soybean cotyledons soaked in different volumes of water. Food Chem 119:1605-12.

Ha EYW, Morr CV, Seo A. 1992. Isoflavone aglucones and volatile organic compounds in soybeans: effect of soaking treatment. J Food Sci 57:414-7.
Hu H, Wu J, Li-Chan ECY, Zhu L, Zhang F, Xu X, Wang GFL, Huang X, Pan S. 2013. Effects of ultrasound on structural and physical properties of soy protein isolate (SPI) dispersions. Food Hydrocoll 30:647-55.

Izumi T, Piskula MK, Osawa S, Obata A, Tobe K, Saito M, Kataoka S, Kubota Y, Kikuchi M. 2000. Soy isoflavone aglycones are absorbed faster and in higher amounts than their glucosides in humans. J Nutr 130:1695-9.

Lima FS, Ida EI. 2014. Optimisation of soybean hydrothermal treatment for the conversion of $\beta$-glucoside isoflavones to aglycones. LWT-Food Sci Technol 56:232-9.

Liu C, Wang X, Ma H, Zhang Z, Xiao L, Gao W. 2008. Functional properties of protein isolates from soybeans stored under various conditional. Food Chem 111:29-37.

Lui MCY, Aguiar CL, Alencar SM, Scamparini ARP, Park YK. 2003. Isoflavonas em isolados e concentrados proteicos de soja. Ciência e Tecnologia de Alimentos 23:206-12.

Malaypally SP, Ismail B. 2010. Effect of protein content and denaturation on the extractability and stability of isoflavones in different soy systems. J Agric Food Chem 58(16):8958-65.

Matsuura M, Obata A. 1993. $\beta$-glucosidases from soybeans hydrolyse daidzin and genistin. J Food Sci 58:144-7.

Naczk M, Grant S, Zadernowski R, Barre E. 2006. Protein precipitating capacity of phenolics of wild blueberry leaves and fruits. Food Chem 96:640-7.

Nahas EA, Nahas-Neto J, Orsatti FL, Carvalho EP, Oliveira ML, Dias R. 2007. Efficacy and safety of a soy isoflavone extract in postmenopausal women: a randomized, double-blind, and placebo-controlled study. Maturitas 58(3):249-58.

Phillips LG, Haque Z, Kinsella JE. 1987. A method for the measurement of foam formation and stability. J Food Sci 52(4):1074-5.

Pinto MS, Lajolo FM, Genovese MI. 2005. Effect of storage temperature and water activity on the content and profile of isoflavones, antioxidant activity, and in vitro protein digestibility of soy protein isolates and deffated soy flours. J Agric Food Chem 53:6340-6.

Privalov PL. 1979. Stability of proteins: small globular proteins. Adv Protein Chem 33:167-236.

Shao S, Duncan AM, Yang R, Marcone MF, Rajcan I, Tsao R. 2009. Tracking isoflavones: from soybean to soy flour, soy Protein isolates to functional soy bread. J Funct Foods 1(1):119-27.

Sorgentini DA, Wagner JR, Añón MC. 1995. Effects of thermal treatment of soy protein isolate on the characteristics and structure: function relationship of soluble and insoluble fractions. J Agric Food Chem 43:2471-9.

Sosulski F, Humbert ES, Bui K, Jones JD. 1976. Functional properties of rapeseed flour, concentrates and isolate. J Food Sci 41(6):1349-76.

Stanley DW, Aguilera JM. 1985. A review of textural defects in cooked reconstituted legumes: the influence of structure and composition. J Food Biochem 9(4):277-323.

Takeiti CY, Sousa AS, Netto FM. 2004. Influência do tratamento térmico nas propriedades de solubilidade e de emulsificação de isolados proteicos de soja e de seus hidrolisados enzimáticos. Brazilian J Food Technol 7(1):87-101.

Tipkanon S, Chompreeda P, Haruthaithanasan V, Suwonsichon T, Prinyawiwatkul W, Xu Z. 2010. Optimizing time and temperature of enzymatic conversion of isoflavone glucosides to aglycones in soy germ flour. J Agric Food Chem 58(21):11340-5.

Wagner JR, Sorgentini DA, Añón MC. 2000. Relation between solubility and surface hydrophobicity as an indicator of modifications during preparation processes of commercial and laboratory-prepared soy protein isolates. J Agric Food Chem 48:3159-65.

Wang H, Murphy PA. 1996. Mass balance study of isoflavones during soybean processing. J Agric Food Chem 44:2377-83.

Wolf WJ. 1979. Soybean proteins: their functional, chemical and physical properties. J Agric Food Chem 18(6):969-76. 